\title{
Dermoscopy features for the diagnosis of furuncular myiasis
}

\section{Características dermatoscópicas para diagnosticar miíase furunculóide}

\author{
Leonardo Spagnol Abraham, M.D. ${ }^{1,2,4}$ \\ Danielle de Paula Aguiar, M.D. ${ }^{1}$ \\ Giuseppe Argenziano, M.D. ${ }^{5}$
}

\author{
Luna Azulay-Abulafia, M.D., Ph.D. ${ }^{1,3,4}$ \\ Fernanda Torres, M.D. ${ }^{4}$
}

\begin{abstract}
We describe a 56-year-old Brazilian woman presenting three nodular lesions on the scalp. Dermoscopy of all lesions showed a creamy-white body with central bird's feet-like structures surrounded by a thorn crown, corresponding to the posterior segment of the Dermatobia hominis larvae. These novel dermoscopic features allowed us to easily diagnose furuncular myiasis.

Keywords: Dermoscopy; Diagnosis; Myiasis; Parasitic diseases

Resumo: Descrevemos o caso de uma paciente brasileira de 56 anos de idade do sexo feminino que apresentou três lesões nodulares no couro cabeludo. A dermatoscopia das lesões mostrou um corpo branco-amarelado com uma estrutura central similar a pés de pássaro, circundado por uma coroa de espinhos, correspondendo ao segmento posterior das larvas de Dermatobia hominis. Estas novas características dermatoscópicas nos permitiram diagnosticar facilmente miíase furuncular.

Palavras-chave: Dermoscopia; Diagnóstico; Doenças parasitárias; Miíase
\end{abstract}

\section{BACKGROUND}

Dermoscopy has proved to be very useful in several dermatologic conditions.$^{1-3}$ The term entodermoscopy was used to describe the use of dermoscopy for the diagnosis of skin infections and infestations. This is a new and interesting application of this technique, which might be useful to dermatologists in areas where these conditions are common, such as in tropical countries. ${ }^{5,6}$

Myiasis is the infestation of the skin by the larval stage of different botflies, mainly Dermatobia bominis. $^{7.9}$ Furuncular myiasis is common in Mexico, Central and South America. In developed countries, it is only occasionally seen as a travel-associated dermatosis. ${ }^{7}$ Even in Brazil, where this is a very common dermatosis, many physicians may not be aware of this condition, which is commonly misdiagnosed as boils and treated with antibiotics.

We describe a case of a furuncular myiasis with its associated dermoscopic features.

\section{OBSERVATIONS}

We present a 56-year-old Brazilian woman complaining of 3 nodular lesions on the scalp, which had appeared 6 weeks before. She presented with 3 nonhealing, painful boil-like lesions, draining a serosanguineous fluid from the central pore (Figure 1). The lesions were accompanied by a stinging and movement sensation inside the nodule. She had recently returned from a trip to a rural area.

Dermoscopy showed the posterior segment of the larva with its breathing spiracles looking like bird's feet. Those structures were seen in the center of a creamy-white body that was surrounded by black dots shaped as a thorn crown and representing small spines in a circular row (Figure 2). The larva fed in a subdermal cavity for 5-10 weeks, breathing through a pore in the host's skin, as demonstrated in the video.

The diagnosis of furuncular myiasis was established and the patient underwent a surgical procedure to extract the larva.

Approved by the Advisory Board and accepted for publication on 06.01.11.

* Work conducted at the Department of Dermatology, Instituto de Dermatologia Prof. Rubem David Azulay, Rio de Janeiro, Brazil.

Conflict of interest: None / Conflito de interesse: Nenbum

Financial funding: None / Suporte financeiro: Nenbum 


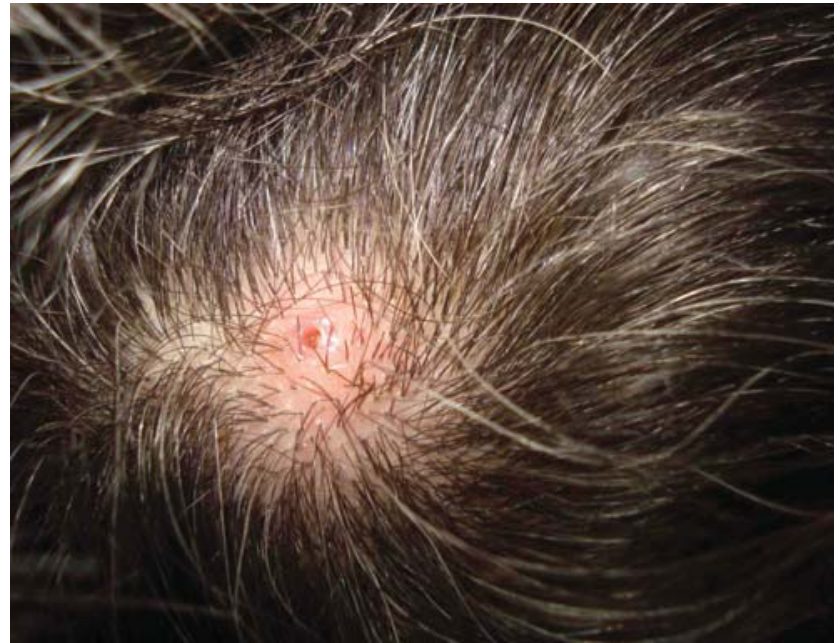

FIGURE 1: An erythematous nodule with a central dilated pore on the scalp of a 56-year-old Brazilian woman

\section{DISCUSSION}

Dermoscopy of furuncular myiasis had been previously described in two papers, in which a central opening surrounded by dilated blood vessels was observed, containing a yellowish structure with black barblike spines extruding intermittently at the periphery.

Our patient presented 3 lesions on the scalp, all showing the same dermoscopic findings. Multiple lesions might be present in the same host, with up to 4060 lesions previously reported in the same individual. ${ }^{7}$

In this case, we could better observe the posterior aspect of the larva. This segment is formed by a central bird's feet-like structure, which corresponds to the opening of the breathing spiracles. ${ }^{10}$ Surrounding this area, we observed barblike spines, which appeared similar to a thorn crown. Dermoscopy also allowed us to observe the larva's movements and breathing. ${ }^{5,6}$

We believe that, in such cases, using oil as an interface fluid is an advantage, since with the occlusion the larva is forced to emerge to the skin surface, where it can be better observed. This observation must be done patiently, as it can take some minutes until the larva emerges. The oil also helps to reveal the bubbles originated by the larva breathing (see the Video on line).

This technique allowed us to easily establish the correct diagnosis of furuncular myiasis and immediately exclude other differential diagnoses, such as bacterial furuncle, infected epidermoid cyst, tungiasis, and cutaneous larva migrans. ${ }^{7}$

Since the larvae of many flies can cause this condition, it is important to stress that these dermoscopic features were described for furuncular myiasis

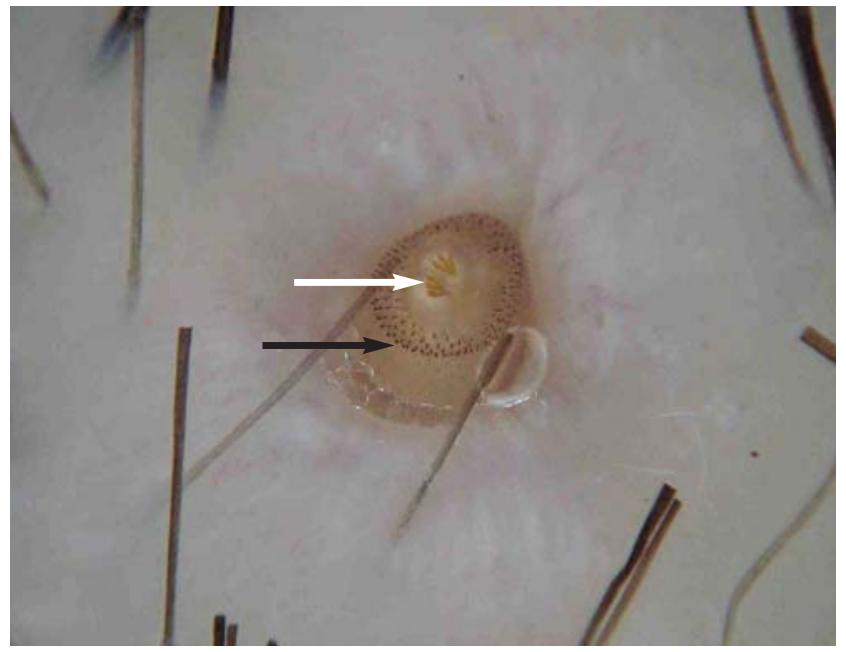

Figure 2: Dermoscopy shows the posterior aspect of the larva. In the center, two bird's feet-like structures (white arrow) correspond to the breathing spiracles. At the periphery of the creamy-white larva, black dots are seen resembling a thorn crown (black arrow). Dermoscopic images were taken with a Sony Cybershot ${ }^{\oplus}$ W55 digital camera connected to a DermLite ${ }^{\circledast}$ handheld II Hybrid $m$ dermoscope, 3Gen, LLC, San Juan Capistrano, California, USA; magnification $10 \mathrm{x}$

Video available online at
http://www.anaisdedermatologia.org.br/
Video description
Contact dermoscopy with oil as interface fluid showing the
Dermatobia hominis larva. The larva moves up and down
through the central pore of a boil-like lesion. The bubbles
produced by the breathing larva are easily observed. The
video was taken with a Sony Cybershot ${ }^{\circledast}$ W55 digital came-
ra connected to a DermLite ${ }^{\varpi}$ handheld II Hybrid m dermos-
cope, 3Gen, LLC, San Juan Capistrano, California, USA,
magnification 10x.

caused by $D$. bominis. In Africa, myiasis is mostly due to the larvae of the flies Cordylobia anthropophaga and C. rbodaini, whereas in the northern hemisphere (North America, Europe, Africa, Asia), it can be caused by the larvae of Hypoderma spp. ${ }^{9}$ The dermoscopic patterns of these agents have not yet been described.

\section{CONCLUSION}

Dermoscopy has proved itself a useful tool for the diagnosis of furuncular myasis. We presented new features in the field of entodermoscopy, namely bird's feet and thorn crown like structures corresponding, respectively, to the posterior spiracles used by the larva for breathing and the small spines surrounding them.

\section{ACKNOWLEDGEMENTS}

We are very thankful to Guilhermo Loda and Vitor Azulay for the surgery. 


\section{REFERENCES}

1. Micali G, Lacarrubba F. Introduction. In: Micali G, Lacarrubba F, editors Dermatoscopy in Clinical Practice: Beyond Pigmented Lesions. Colchester: Informa Healthcare; 2010. p.1.

2. Abraham LS, Torres FN, Azulay-Abulafia L. Dermoscopic clues to distinguish trichotillomania from patchy alopecia areata. An Bras Dermatol. 2010;85:723-6.

3. Abraham LS, Piñeiro-Maceira J, Duque-Estrada B, Barcaui CB, Sodré CT. Pinpoint white dots in the scalp: dermoscopic and histopathologic correlation. J Am Acad Dermatol. 2010;63:721-2.

4. Zalaudek I, Giacomel J, Cabo H, Di Stefani A, Ferrara G, Hofmann-Wellenhof R, et al. Entodermoscopy: a new tool for diagnosing skin infections and infestations. Dermatology. 2008;216:14-23.

5. Bakos RM, Bakos L. Dermoscopic diagnosis of furuncular myiasis. Arch Dermatol. 2007;143:123-4.

6. Llamas-Velasco M, Navarro R, Santiago Sánchez-Mateos D, De Argila D. Dermoscopy in furuncular myiasis. Actas Dermosifiliogr. 2010;101:894-6.

7. Maier $\mathrm{H}$, Hönigsmann $\mathrm{H}$. Furuncular myiasis caused by Dermatobia hominis, the human botfly. J Am Acad Dermatol. 2004;50(2 Suppl):S26-30.

8. Centers for Disease Control \& Prevention (CDC's), Division of Parasitic Diseases. [Accessed April 3 2010.]. Avaiable from: http://www.dpd.cdc.gov/DPDx/HTML/Myiasis.htm.
9. Clyti E, Pages F, Pradinaud R. Update on Dermatobia hominis: South American furuncular myiasis. Med Trop (Mars). 2008;68:7-10.

10. Möhrenschlager M, Mempel M, Weichenmeier I, Engst R, Ring J, Behrendt H. Scanning electron microscopy of Dermatobia hominis reveals cutaneous anchoring features. J Am Acad Dermatol. 2007;57:716-8.

MAILING ADDRESS / ENDEREÇO PARA CORRESPONDÊNCIA:

Leonardo Spagnol Abraham

R. Coelbo Neto, 32/201, B. Laranjeiras

Zip Code: 22231-110 Rio de Janeiro - RJ, Brazil

Telephone number: +5521 9218-4164/ +5521

2553-4928

Email: leosabraham@gmail.com

How to cite this article/Como citar este artigo: Abraham LS, Azulay-Abulafia L, Aguiar DP, Torres F, Argenziano G. Dermoscopy features for the diagnosis of furuncular myiasis. An Bras Dermatol. 2011;86(1):160-2. 